\title{
Power struggle hits Swedish institute
}

It was meant to be a year of glorious celebration for Stockholm's Karolinska Institute. But the bicentenary of the venerable medical university, which selects the winners of the Nobel Prize in Physiology or Medicine, has been soured by an acrimonious row.

On 27 July, 12 top Karolinska scientists published an open letter in Sweden's leading daily newspaper, Dagens Nyheter, claiming that the institute faces a growing threat from its own president.

The scientists - 10 of whom sit on the 15-strong Nobel selection committee charge that institute president Harriet Wallberg-Henriksson has used her position over the past six years to inappropriately concentrate power into her own hands, increasing bureaucracy for researchers and suppressing critical voices by ousting those who stand in her way. They say that "an emergency brake needs to be pulled" on proposals to formally extend the decisionmaking power of the president. The proposals, open for comment from faculty members until mid-September, are part of a wider management reorganization being prepared by the president and her board in anticipation of a new law giving more autonomy to Swedish universities, which comes into force in January 2011.

Wallberg-Henriksson says the concerns are based on misunderstandings, and that she "welcomes a debate about the development of our university, its organization and its leadership". She insists that she has not appropriated new powers during her term in office, and that she wants to avoid her office gaining too much power in the reorganization. Hostilities have reached such a pitch, however, that some of the institute's 300 professors are refusing to attend a high-profile Jubilee Banquet with King Carl XVI Gustaf on 27 August.

Tempers first erupted publicly in March, when Wallberg-Henriksson dismissed molecular pathologist Karl Tryggvason from his position of research dean without notice or consultation, after an internal investigation concluded that he had tried to unduly influence a grant committee's selection process. The committee was responsible for distributing a fund established by Tryggvason to support prominent Karolinska professors.

The investigation found that Tryggvason had e-mailed the selection committee to suggest alternatives for two shortlisted candidates who turned out to be ineligible (see Nature doi:10.1038/news.2010.144; 2010). Tryggvason admitted that he should not have sent the e-mail but insisted that he had no connection with the scientists he recommended. He retains his position as professor of medical chemistry at the institute.

The dismissal "was a shock, because Tyggvason was a dynamic force at the Karolinska", says biomedical researcher Christer Betsholtz, a Nobel committee member who signed the letter. "He was controversial but he had a strong scientific vision." The letter in Dagens Nyheter says that the charges against him are not convincing.

Critics of WallbergHenriksson also point to the recent departure of senior Karolinska figures as evidence of a systematic silencing of dissenting voices. Vivi-Anne Sundqvist, the dean for higher education, who had clashed with the president over her policies, stood down from the board last year; this year, a former editor of Dagens Nyheter left the board after his mandate was, unusually, not renewed. But the president says the education dean asked to step down and the former editor was simply not reappointed for a second term of office. The allegation of silencing "is of course wrong", she says.

Wallberg-Henriksson agrees that her term has seen researchers bearing a greater bureaucratic burden, such as more detailed documentation of spending, but says that this is due in part to demands for greater accountability from the government and from funding agencies. She says that the new autonomy for universities will free her hand to reduce bureaucracy.

The proposed reorganization would reshape the Karolinska Institute's current three academic boards - for research, education and graduate education - and create above them a coordinating board, headed by the president. This board would include representatives from the faculties. Although proponents claim that the plan will improve coordination between the university's different functions, critics say that it will dilute the voices advocating for research and teaching.

The professors behind the letter in Dagens Nyheter demand more power-sharing between the president and elected deans so that faculty members have a stronger voice in decision-making. "Things need to be more democratic," says paediatrician Hugo Lagercrantz, who signed the letter. "A university is not a company." WallbergHenriksson told Nature that the proposal is only a suggestion, and conceded that "it might not be a good idea if the president is head of the coordination board".

The law driving the reorganization is part of a trend over the past 20 years or so for European governments to give their universities more autonomy, allowing them to manage their own budgets, for example, to make them more flexible and competitive. But universities have adopted different levels of powersharing between academics, the presidents or rectors, and the university boards, says Thomas Estermann of the European Universities Association (EUA) in Brussels. Estermann co-authored a 2009 EUA report, University
Autonomy in Europe 1 - Exploratory Study (see go.nature.com/6aa7uI), showing that increasing autonomy in 34 different countries has had mixed results.

Still, he says, "the Karolinska Institute case is not unusual". Similar clashes with faculty members took place at the Swiss Federal Institute of Technology in Zurich - mainland Europe's top-performing university - where professors forced the reform-minded president to resign and maintained their decision-making powers in the university's organization.

Tensions at the Karolinska Institute are running just as high. "The president is responsible for making the Karolinska more authoritarian and less free, and she should leave," says Lagercrantz. "Given the mood, some leading scientists won't be going to the dinner with the King. I will not be going." Alison Abbott 